\title{
Fire Fighting and Prevention Workers
}

National Cancer Institute

\section{Source}

National Cancer Institute. Fire Fighting and Prevention Workers. NCI Thesaurus. Code C122453.

Workers eng aged in fire fighting and fire prevention and control. 